\title{
WHY GEOMORPHOLOGY IS A GLOBAL SCIENCE
}

\section{J.M. GARCÍA-RUIZ}

Instituto Pirenaico de Ecología, CSIC, Campus de Aula Dei, P.O. Box 13034, 50080 Zaragoza, Spain.

Hypothesize outrageously, geomorphologists, you have nothing to lose but your paradigms

(Baker and Twidale, 1991)

\begin{abstract}
Geomorphology is a highly complex science that involves elements of geography and geology, and concerns the study of, and explanations for, landforms at various temporal and spatial scales. This review focuses on those aspects of geomorphology that highlight its global importance. Landforms are the result of the activity of geomorphic processes on geological structures, occurring over varying time scales. Each landform is the consequence of a complex interaction between bedrock, changing climate, biological activity, geomorphic processes and time. The role of geomorphologists is to unravel this complexity from the relief, where the remnants of past deposits and landforms constitute a palimpsest from which most information has disappeared. Interpreting the relief and its dynamics necessitates detailed analysis, increasing use of remote sensing and GIS techniques, and especially a global perspective. The collaboration of geomorphologists with ecologists has contributed to enhance the role of geomorphologists in environmental studies.
\end{abstract}

\section{Por qué la geomorfología es una ciencia global}

RESUMEN. La Geomorfología es una ciencia muy compleja desarrollada entre la Geografía y la Geología, con el objetivo de estudiar y explicar las formas de relieve a diferentes escalas espaciales y temporales. Este trabajo revisa aquellos aspectos que confirman la necesidad de ser global en Geomorfología. Las formas de relieve son el resultado de la actividad de procesos geomórficos sobre una estructura geológica durante un periodo de tiempo muy variable. Cada forma de relieve es consecuencia de una interacción compleja entre sustrato rocoso, disposición estructural, clima, actividad biológica, procesos geomórficos y tiempo. El papel de los geomorfólogos es desentrañar esa complejidad a partir del relieve actual, en el que los restos de formas de relieve y depósitos de diferente origen dan lugar a un palimpsesto en el que la mayor 
parte de la información ha desaparecido. La interpretación del relieve y su dinámica necesita análisis detallados y el empleo creciente de técnicas ligadas a ordenadores (teledetección y SIG), y especialmente una perspectiva global para interpretar el relieve y su dinámica. La colaboración con ecólogos ha contribuido a ampliar la función de los geomorfólogos en los estudios ambientales.

Key words: Geomorphology, global science, landforms, landscape, catchment scale.

Palabras clave: Geomorfología, ciencia global, formas de relieve, paisaje, escala de cuencas.

*Corresponding author: Instituto Pirenaico de Ecología, CSIC, Campus de Aula Dei, P.O. Box 13034, 50080 Zaragoza, Spain. E-mail: humberto@ipe.csic.es

\section{Introduction}

Geomorphology is a relatively young science, although its roots are very ancient. Thus, Chorley et al. (1964) pointed out that the first recorded observations and interpretations concerning relief and topography emerged in ancient Greece, including pioneering ideas on fluvial incision and the hydrological cycle (Bauer, 2004). Nevertheless, the consolidation of geomorphology among the environmental sciences occurred during the 18th and particularly the 19th centuries, with the practical and theoretical works of Hutton (1726-1797; Theory of the Earth), Lyell (1797-1875; Principles of Geology), and G. K. Gilbert (1843-1918; Report on the geology of the Henri mountains, and Lake Bonneville). Hutton is considered by some geomorphologists to be the founder of modern geomorphology (Bauer, 2004). During Hutton's time, nature was an open book ready to be discovered and interpreted, and the success of geomorphologists lay in their precise observation of landforms and deposits. Most probably they were independent scientists. Geographers and geologists related landforms to various structural aspects of the Earth's surface or to ancient cold climatic stages, and built the basis for explaining the temporal and spatial aspects of the relief. The classification and description of landforms were the basis for an increasingly consistent science.

Some authors consider that geomorphology "has suffered from an identity crisis since its inception in the late 1800s" (Rhoads and Thorn, 1993). This has been attributed in part to the division of the discipline between geographers and geologists, and their respective spatial and temporal perspectives. For many human geographers, geomorphology is exclusively a part of the environmental sciences; they do not understand the role of periglacial, glacial or karst studies within geography, a science that they consider (in my opinion erroneously) to be "social". 
Baker and Twidale (1991) criticized the abandonment of physical geography by geography departments in some universities, which chose to emphasize social and statistical aspects; the names of many departments were changed to such titles as Geography and Planning, or Geography and Land Management. The position of geomorphology within geology is no better. For decades most 'heavy' geologists (e.g. geophysicists, geochemists, tectonicists) considered geomorphology to be a 'soft' science, concerned with the study of a thin layer at the Earth's surface and considering very short temporal scales (thousands of years rather than tens or even hundreds of millions of years). Some geomorphologists consider that geomorphology is threatened by the dramatic growth of Quaternary studies (Thorn, 1988), which focus more on environmental changes during the Quaternary than on landforms.

For decades, geomorphology has focused strictly on the study of relief in relation to rock resistance and structural layout, and its evolution in alternating cold/hot or dry/ humid climates. This was a problem, and perhaps contributed to the development and initial success of the geographical cycle of William M. Davies, reducing the relationships between geomorphology and other environmental sciences, and limiting development of the "global dark side" of geomorphology. I am sure that geomorphology has been a holistic science since its inception, even though most geomorphologists are not conscious of this. The recent Balkanization of environmental studies (according to Tricart, 1978) has contributed to the development of small-scale studies increasingly focused on experiments, and a view more interested in that we have beneath our feet and less focused on the interpretation of the landscape, to which geomorphologists have an enormous potential to contribute. This review concerns those aspects that confirm the necessity of geomorphology being global if it is to be effective. Few sciences are in the privileged position of being ecological in nature, and geomorphology is certainly one of them.

\section{What is geomorphology?}

Definitions of geomorphology are consistent among most authors, although some differences occur. For instance, the classical definition by Derruau (1965) states that geomorphology is the study of the landforms of the Earth's relief, and this author also noted that like all natural sciences, geomorphology aims to describe and explain. Panizza (1996) defined geomorphology as "a science which aims to study and interpret landforms and especially the causes that create and modify them". Bauer (2004), in the Encyclopedia of Geomorphology, defined geomorphology as "the area of study leading to an understanding of an appreciation for landforms and landscapes, including those on continents and islands, those beneath oceans, lakes, rivers, glaciers and other water bodies, as well as those on the terrestrial planets and moons of our Solar System". For Gutiérrez (2005), "Geomorphology is the science of the form of the land surface". Landform and relief are key words in most definitions. Most geomorphologists would probably describe the aim of their work to be "the study and explanation of the relief" or similar, irrespective of whether their research involved rainfall simulations in plots $<0.5 \mathrm{~m}^{2}$ or the study of isotopic characteristics 
of lacustrine sediments. For most geomorphologists, the scale at which they work and the context in which it is performed are not of importance: they work on relief and landforms, even if they do not use these terms in their publications. Perhaps it would be more appropriate to say that they are a very important part of a geomorphological team comprising specialists focused on various aspects of landform and deposits to reach a global view of the relief, and a holistic interpretation. Thomas (2001) indirectly referred to this organization as a system of "Russian dolls", and Tricart (1978) noted that progression in geomorphology is only possible by using frequent zoom effects. This means that the geomorphologist needs to perform, for example, detailed analyses of deposits, or explain the complex relationships between plants and erosion, to achieve the objective of understanding the relief in temporal and spatial contexts. However, these analyses must provide a general perspective, locating deposits and landforms in a broader context. If a zoom effect is not used, how can one explain OSL analysis in moraines and terraces, or the study of water table fluctuations in sediment transport projects? I know that many geologists and geographers are at the extreme of the zoom or in the smallest Russian doll, but they cannot strictly be considered to be geomorphologists if they do not expand their view to analysis of the landforms from the other extreme of the zoom. For this reason, I propose that geomorphology be defined as the science that studies the evolution and spatial organization of landforms at different temporal and spatial scales. This definition provides a more dynamic perspective of geomorphology, and at the same time incorporates space and time, both of which are crucial in explaining landforms.

\section{Geomorphology and landscape}

Since the 18th century geomorphologists have tried to explain landforms and landscape using various theoretical frameworks. Religion has always tried to control the development of science, and to adapt scientific advancements to the most conservative biblical ideas of the Earth's development, based in the most restrictive reading of the Bible. This explains the initial success of catastrophism in justifying rapid landscape development over short periods of time. Fortunately, the uniformitarianism of Lyell represented a rationalization of landscape development (Bauer, 2004), based on the uniformity of laws and processes. The most significant idea of Lyell was that "the present is the key of the past" (referred to by Gutiérrez, 2005). This means that the explanation for landform development rests on geomorphic processes occurring at present; in other words, that old landforms can be studied in the light of present processes. This consistent idea led to the relatively early development of climatic geomorphology, a concept first introduced by De Martonne in 1913 in the publication Le climat, facteur du relief. Surprisingly, the geographical cycle (or erosion cycle) of W. M. Davis (1899) gave secondary roles to the spatial and temporal variability of climate, such that the relief is a consequence of structure, processes and time (Sack, 1992). Davis concluded that relief evolved through stages of youth, maturity and old age, providing a simplistic and deterministic view of landscape evolution, the end product of which would be a peneplain (Leopold et al., 1964). For Davis, and perhaps more-so for students of his views, the identification of 
certain landscape characteristics was sufficient to provide information on past and future landscape development. Perhaps this was the reason for the popularity of Davis' geographical cycle and ideas, which dominated geomorphological investigations until the mid-20th century. Some authors have stressed, perhaps overly, that Davis' ideas were responsible for decades of backwardness in the science of geomorphology relative to other environmental sciences (Tricart, 1965), particularly because of the marginalization of climate-driven geomorphic processes (e.g. Passarge, 1931). A change in paradigm occurred with Strahler (1952) and Leopold et al. (1964), who gave a marked impetus to geomorphology by emphasizing the role of field and laboratory research, physics and mathematics in quantitative geomorphology, which was pioneered by the studies of Horton (1945) on the morphometry of rivers and basins. From theoretical, extremely complex and valuable approaches, some authors established simplistic solutions, classifying countries, schools and scientists as geomorphologically positivist, historicist or non-positivist (Capel, 1983).

Prior to Strahler most geomorphology was historical; that is, the interpretation of landforms was in relation to series of events that occurred over thousands of years. Subsequently, geomorphologists increasingly studied the relationships between scales and processes, and incorporated experimentation. This represented a profound change in scales and methods, as well as in the position of geomorphology among the environmental sciences (Thornes, 1979).

The landscape is a complex concept with a complex history. In most places it shows large variability, particularly in mountain areas, and in the narrow contact areas between mountains and lowlands. Such variability is the result of a long history of interactions between endogenous and exogenous forces, and the role of changing processes throughout thousands or millions of years. The landscape has frequently been defined as a palimpsest, such that the materials present are the result of the temporal superposition of many geomorphic processes over a particular geological structure. Some authors refer to polygenetic forms coexisting at the same location (de Boer, 1992; Bauer, 2004; Redondo Vega et al., 2013). Landforms and processes change progressively over time. Tectonics, changes in the base level, and changes in climate and vegetation all leave their imprints in the landscape. Some imprints may have disappeared because of subsequent processes, but many can be deduced through small remnant deposits, or by the presence of landforms associated with past processes (confirming, therefore, the importance of uniformitarianism). Observation and analysis enable detection of past changes in processes and landforms, and (most importantly) identification of the succession of events. Observation under the umbrella of a theory is essential, and theory is in debt with field and laboratory observations. Both are inseparable, although some theoretical papers seem to bring them face to face (Capel, 1983). That is geomorphology!

Some geomorphologists study the historical development of landforms, including pre-Triassic erosion surfaces, the emplacement of the fluvial network, the development of hillslopes, or the imprint of Pleistocene glaciers. A complete sequence of events is very difficult to reconstruct; landforms and deposits usually 
enable the opening of windows that inform about isolated events. The keen-sighted geomorphologist will assess the importance of every window that is opened. It is probable that a Quaternary deposit is the remnant of a marginal event located in a marginal position in a regional context. This interpretation depends on much theory and observation, particularly because geomorphological time is heterogeneous (Tricart, 1965), with irregular development and subject to thresholds. Many processes are time-dependent (Brunsden, 2001); they need a period of time to develop, or occur during low-frequency rainfall events (e.g. debris flows and shallow landslides). Understanding of thresholds and their meaning helps the interpretation of certain aspects of relief development.

Other geomorphologists are mainly devoted to the study of the most recent changes, caused by processes including those that occurred during the Holocene, in the last few centuries, or are contemporary. These include fine-scale detection of climate fluctuations and changes caused by mankind (the Anthropocene!), which are responsible for soil erosion processes, fluvial channel changes and sedimentation. Contemporary processes create new landforms, and partly or totally mask other landforms and deposits. Conversely, some processes are inherited from past geomorphic events. Therefore, the temporal scale at which geomorphologists study landforms is a key factor that is subject to many uncertainties.

Spatial scales introduce complexity into geomorphology. It is well known that geomorphic studies can be focused from plot to regional (or even continental) scales, depending on the study topic and the roles of certain processes; again, the zoom effect of Tricart (1978). Small and large scales are difficult to integrate, and one of the most crucial problems in process geomorphology is that of upscaling and downscaling. For instance, it is noteworthy that erosion processes have been defined as scale-dependent (Cammeraat, 2004; de Vente and Poesen, 2005; de Vente et al., 2007; Vanmaercke et al., 2011a); that is, each scale enables the observation and study of certain processes, but not others. Thus, rainfall simulation can only provide accurate and reliable information on splash processes and rainfall infiltration (e.g. Keesstra et al., 2014), experimental plots yield information on sheetwash erosion and (maybe) rilling, and experimental catchments are useful for studying integrated processes in the hillslopes and channels, including landslides, gullying and channel erosion. For none of the latter is their study possible at finer scales. However, no scale excludes the importance of, or interest in, other scales: consideration of all scales is necessary. Rainfall simulation and experimental plots contribute to interpretation of the characteristics of flood hydrographs, or the spatial variability of sediment and runoff sources at catchment scales. Although not easy, for many geomorphologists understanding changes in scale is essential to understanding soil erosion and hydrology. In fact, those used to working at detailed scales need to have a broader view of landforms and landscapes if they want to be considered true geomorphologists. It is similar for geomorphologists that work at catchment or regional scales: they need information obtained at more detailed scales. This does not mean that information can be easily transferred from one scale to another, as is the case with erosion rates, which are only valid for the scale at which they have been 
determined (e.g. Parsons et al., 2006). One more time, the occurrence of thresholds is key to understanding certain aspects of relief dynamics, including sediment transport by rivers. This explains why analyses of similar rainfall and hydrological events do not yield the same sediment transport values, because of dependence on events that occurred previously.

The "threshold concept" is closely linked to the "landscape sensitivity concept" (Brunsden and Thornes, 1979). A geomorphological threshold is a physical or conceptual change that introduces a sudden change in the functioning of a certain geomorphic system. This is the case with climate change and certain human activities, whose effects on soil erosion or sediment transport may not be appreciated until a threshold is exceeded. At this point a series of geomorphic processes occur that trigger landslides and the development of gullies or channel aggradation, leading to a new geomorphic system. For this reason a linear process-response involving predictable trends is rarely evident (Thomas, 2001), and the result is "chaotic behaviours and patterns" (Phillips, 1992a) that hinder the early identification of critical signs of erosion. Landscape sensitivity refers to the ability of a landscape to resist changes or to produce a complex response, and implies the occurrence of instability in the system (Thomas, 2001). Some geomorphic systems tend to be more stable (e.g. the lowlands, which are characterized by gentle gradients), while others tend to be unstable (e.g. mountain areas, which are defined as high energy systems). Some landscapes can change suddenly, over a few minutes, as is the case in mountain catchments affected by extreme or exceptional events (White et al., 1997) that cause channel incision and sedimentation, and dramatic changes in alluvial fans. Other landscapes change only at very long temporal scales. Examples include periglacial environments having little overland flow, and pediments at the foot of mountain fronts, which can be affected by changes in the geomorphic pattern as a consequence of long-term base level changes. An isolated event can trigger changes in unstable geomorphic systems, whereas changes in the most stable systems are related to long-term environmental change. This means that the concept of equilibrium in geomorphology depends, at least in part, on the temporal scale at which a landscape is perceived. Complexity is perhaps the most outstanding characteristic of geomorphic systems, whose study can only be fully addressed through a holistic perspective. After all, "landscapes contain mixtures of equilibrium, disequilibrium and nonequilibrium landforms" (Renwick, 1992).

\section{The global view of the landscape: catchments and rivers as drivers}

It seems relatively easy to explain why geomorphology is considered a part of geology, because it involves the study of the landforms of the Earth's surface, which represent the culmination of millions of years of evolution. In contrast, it is probable that many geographers (particularly those involved in human geography, but also physical geography) would be unable to adequately explain why it is also considered a part of geography. 
Geography is a broad and frequently misunderstood science. It is as old as the oldest sciences (e.g. mathematics, geometry, philosophy), but has been considered by some to have always been in crisis (Ortega, 1977). Although it is not clear why this is the case, it may be related to the absence of clear objectives. A personal definition of the field of study of the geography discipline is that: Geography is the scientific study of the spatial organization of structures, processes and facts that shape the (visible and invisible) landscapes of the Earth. Landscape is the objective, including its structure and function in any area of the world, including in cities, deserts, mountains or pediments, and whether intensely or barely disturbed by human activity. For instance, the study of telephonic interconnections between the main European cities is as much a concern of geography as the study of the distribution of forests in a mountain range, or the spatial distribution of landslides. At some scale everything is geography; all that is needed is a particular (or special) point of view. This explains why geomorphology is also a part of geography (like biogeography, hydrology and climatology), and why geography is NOT ONLY a social science.

The landscape is a complex system whose elements are interconnected and function as a complex whole (Phillips, 1992b; Scheidegger, 1992). It is the consequence of a combination of landforms, vegetation, climate and human activity (including culture, population density and the effects of regional and international markets) as the main drivers. The study of these factors is thus a matter of geography, providing they are viewed as a part of the Earth's complexity. For geographers, geomorphology (that is, the study of landforms) is a crucial part of geography in both its historical and spatial aspects (Photo 1). This does not preclude geomorphology being shared with geologists, although their methods and objectives may be slightly different. I do not understand why some regional or human geographers reject the possibility of a dynamic geomorphology, in collaboration or competing with geologists (García-Fernández, 2001). For many geographers, geomorphology (like climatology, hydrology and biogeography) cannot develop with its own methods and theories.

It is evident that geomorphology has a historical component involving study of the development of landscapes, particularly during the Quaternary. Even in this aspect geomorphologists need to adopt a global approach, including the use of paleoclimatic and paleoecological resources. Nevertheless, it is the study of contemporary (or relatively recent) geomorphic problems that necessitates a global approach by geomorphologists. Baker and Twidale (1991) see geomorphology "as an holistic, chronological, integrative field-based science, that is integral to the study of a dynamically vibrant planet", and they "trust that in the not too distant Geomorphology will again be seen as an integral part of, on the one hand, geneticallyoriented holistic studies intent on understanding the present spatial distribution and interrelationships of earthly phenomena, and, on the other, of studies concerned to analyze and explain the evolution of the Earth through time". This holistic perspective is related to two distinct geomorphic approaches: (i) the historical approach; and (ii) the analysis of geomorphic processes to explain dynamic functional aspects of the contemporary landscape. 


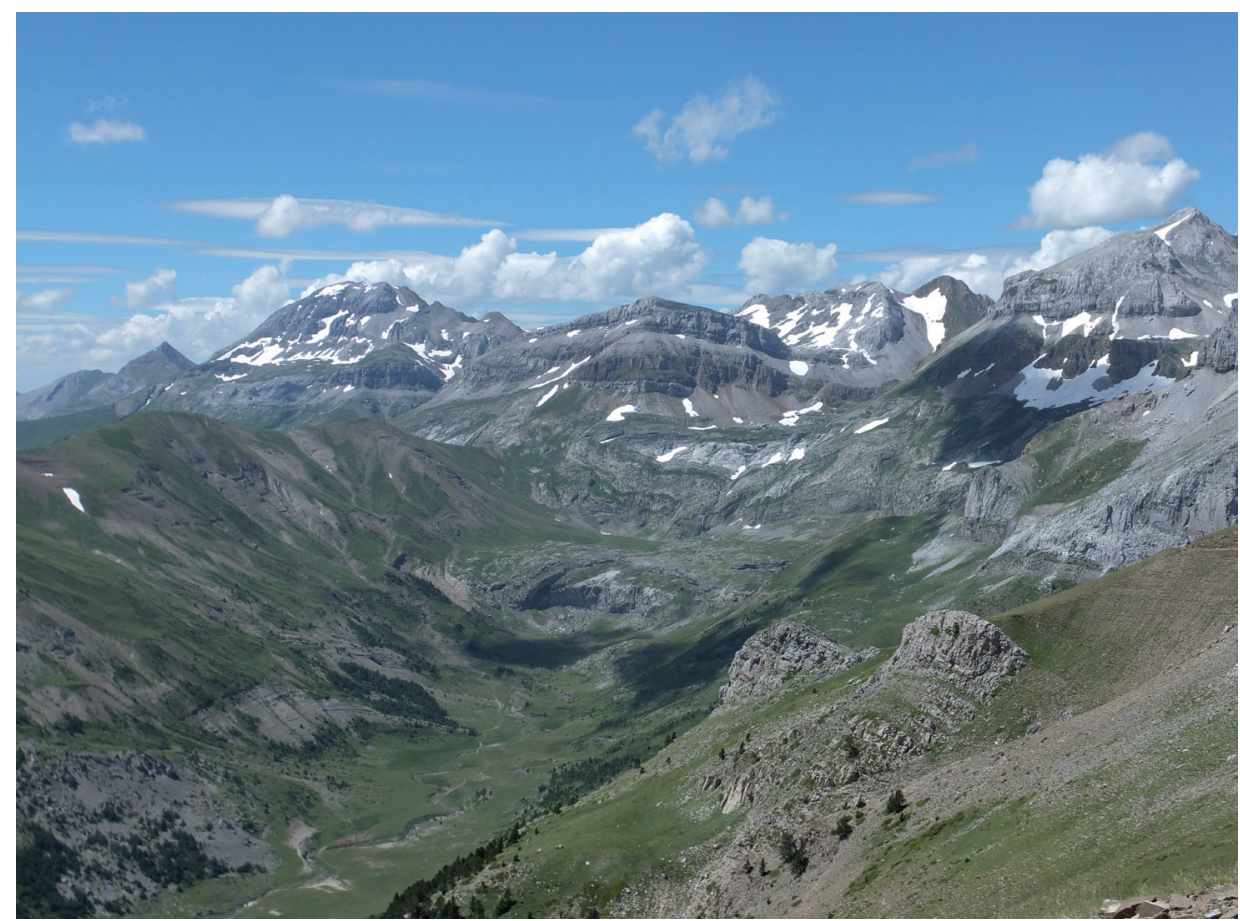

Photo 1. Headwater of the Aisa Valley, central-western Spanish Pyrenees. The high reliefs of the Inner Ranges (Bisaurin Peak, the Bernera perched syncline, and the Aspe Peak) are characterized by abrupt scarps made of Cretaceous and Eocene limestone and sandstone, with alternating cliffs and taluses. At least two overthrusting anticlines result in two topographic thresholds along the main valley. In the foreground, a Pleistocene glacier developed the wide $U$-shaped Aisa Valley. The main divide in the flysch sector, at approximately $2100 \mathrm{~m}$ a.s.l., is an old erosion surface. The flysch outcrops appear to have been colonized by summer grasslands following deforestation in the Middle Ages, which triggered intense erosion processes (gullies, shallow landslides, active headwaters) and resulted in the formation of small alluvial fans. The small patches of Pinus sylvestris are the remnants of the old forest. This view represents the lithological contrasts and the strong influence of structure as a basis for the development of different landforms. The U-shaped valley was also conditioned by lithology and the occurrence of lithological thresholds. Erosion following deforestation is a recent environmental problem that conditions many landforms on hillslopes and valley bottoms. Photo: José M. García-Ruiz.

(i) In the first case landforms are the result of a long history of slow and catastrophic processes that occurred since the uplift of oceanic basins to the Earth's surface, in most cases over tens of millions of years. The contemporary landforms are the consequence of a succession of events under different climates, each of which left imprints in the form of deposits and landforms (Photo 2). Many of these imprints have disappeared because of subsequent processes, and reconstructing the landscape development processes or explaining the contemporary landforms is extremely difficult. Achieving these objectives requires a profoundly holistic effort, including the use of distinct dating techniques, and interpretation of the relative position of landforms and deposits to enable reconstruction 
of past landscapes. This is a difficult task that can easily lead to erroneous conclusions because of the absence of many imprints. Fortunately, there is an increasing number of tools available to date deposits and landforms (enabling ordering of many of the events), or to obtain information on past processes. Gaps in the evolution are (and will remain) usual, although improvements to techniques and geomorphic theory could reduce them in the future. Nevertheless, in some cases there is dissociation of the new geochronological and sedimentological techniques from the geomorphological study of landforms and landscapes. For instance, studies on lake sediments can contribute to climate and vegetation reconstruction, but also to relating sediment characteristics to the development of landforms in the drainage area, and to identifying the corresponding erosion processes. This is one of the challenges for geomorphologists in the near future: to get more geomorphological information from paleoclimate information and lake sediments.

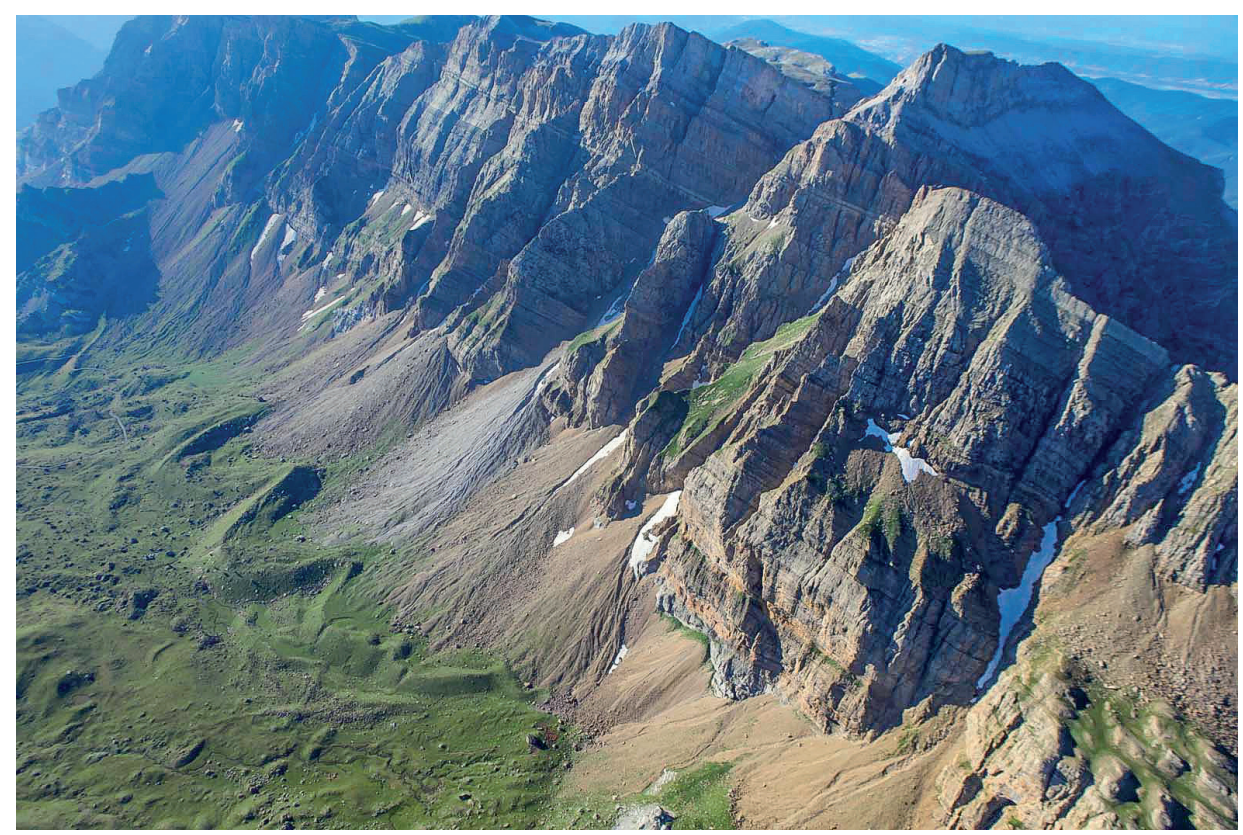

Photo 2. The north face of the Telera Range, Upper Gállego Valley, central Spanish Pyrenees. The north face is composed of a large, almost vertical cliff made of Cretaceous and Eocene limestone and sandstone. The cliff has been shaped by snow and ice avalanches, which resulted in major incisions related to vertical fractures. Large debris cones have developed at the foot of the cliff, where the products of erosion in the avalanche canals have accumulated, in part related to debris flows. At the front of the debris cones there is a series of end moraines (or a mixture of moraines and protalus ramparts) having the typical half-moon shape. These moraines were most likely deposited during the last Pleistocene cold period (Younger Dryas) by small ice masses accumulated from avalanches. Other moraine remnants appear scattered in the extreme left of the picture, representing short glacial advances during the deglaciation period. This is a good example of the superposition of distinct geomorphic phenomena in a small area, with active avalanche canals affecting a structural scarp, and moraines resulting from glacial activity some thousands of years ago. Photo: Francisco Gutiérrez Santolaya. 
(ii) In the second case, geomorphic processes are affected by a large number of factors. The study of contemporary geomorphic functioning requires extensive knowledge of fluvial geomorphology, landslides, the relationships between soil erosion and plant cover, pedology, soil erosion processes (sheet wash erosion, rilling, gullying, splash), the connectivity between hillslopes and channels, remote sensing, geographic information systems, and even land use changes in recent centuries (Goudie, 1981), because humans have the ability to create new landforms (bench terraces, subsidences, slag heaps). Population growth and socioeconomic crises could necessitate the enlargement of cultivated areas, favoring the expansion of shifting agriculture, which could result in an increase in soil erosion and sediment transport. It is impossible to understand the geomorphic role of mankind and its severe environmental effects without a global perspective. Understanding the latter is essential for efficient environmental management, and to answer many questions related to global change (Goudie, 2002). Many studies have focused on partial aspects of geomorphic processes, including the retreat of gullies, infiltration under distinct plant covers, and the relationships between raindrop characteristics and particle detachment. The necessity of these and similar studies is not addressed here, but the role of a geomorphologist is to interrelate this information and provide a global perspective of landscape functioning (Photo 3).

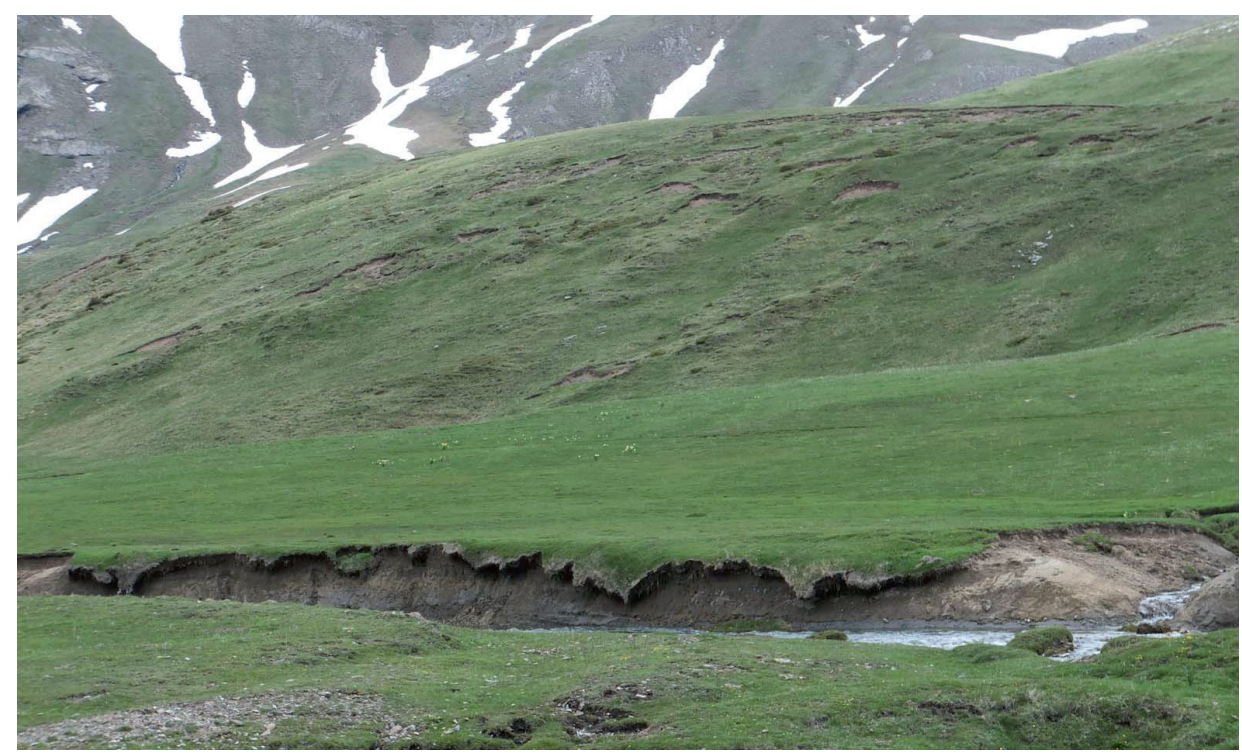

Photo 3. The subalpine belt in the Agüerri Valley and the Plandániz paleo-lake, Upper Hecho Valley, central-western Spanish Pyrenees. The image shows hillslopes affected by active shallow landslides and a valley bottom occupied by a glacial paleo-lake that has been filled with sediment.

The shallow landslides are the result of deforestation of this part of the subalpine belt to enlarge the area occupied by summer grasslands. Landsliding has resulted in a redistribution of soil and nutrients on the hillslope, and in the transfer of large quantities of soil to the valley bottom.

Nevertheless, the sediment has not entered the river because of the presence of an almost flat topography, related to the development of a paleo-lake immediately following deglaciation. Riverbank erosion, and not hillslope erosion, is responsible for the sediment load in the stream, despite the intense geomorphic activity in the hillslopes. This demonstrates the difficulties in relating sediment yield at the outlet of a catchment to soil erosion on the hillslopes. Photo: José M. García-Ruiz. 
Historical development or contemporary processes? This key question for geomorphologists was addressed by Schumm (1977), who stated: “...it is possible to view the [fluvial] system either as a physical system or as a historical system. In actuality it is a physical system with a history" (p. 10). This explains why it is so difficult to develop successful fluvial restoration plans. A stretch in a river is characterized by morphology and sediment transport, but the question is: what determines morphology and sediment transport in that river stretch? It is not always easy to derive the answer: it may be the result of historical factors, or the consequence of land use changes in one or several areas in the basin involved. In any case, restoration of that stretch could fail because of sediment carried from upstream, or for many other reasons. Only a global perspective of the alluvial plain in relation to the geomorphic dynamics of the basin could inform some interpretations (e.g. Ollero et al., 2014). Probably for this reason Tricart (1978) stated that integrated land management at a basin scale must begin from the headwater, taking into account the hillslopes and the fluvial channel because of the interrelationships between these aspects of the relief. In many cases efforts to reduce connectivity between hillslopes and channels may be ineffective because the expansion of shrubs and forest in the former causes a decline in hillslope sediment yield, leading to incision in the fluvial channel and bank erosion (Trimble, 2009; Gómez-Villar et al., 2014; Sanchis-Ibor and Segura-Beltrán, 2014; Sanjuán et al., 2014) (Photo 4).

Many approaches have been used in the study of soil erosion, to obtain soil erosion rates for comparisons among different environments, and to investigate silting problems in reservoirs. Depending on the characteristics of research teams and the availability of financial resources, these approaches vary from rainfall simulations to modeling, experimental plots, the use of radionuclides, assessment of sediment accumulation in reservoirs, and experimental catchments. Several studies have revealed that erosion rates obtained using these methods are extremely variable (e.g. de Vente et al., 2007), because each method was devised for the study of distinct erosion and transport processes. Nevertheless, there is agreement in that small catchments (tens to hundreds of hectares) are excellent for study of the natural functioning of landscapes (e.g. García-Ruiz et al., 2010; Vanmaercke et al., 2012). This is logical: the study area is sufficiently large to enable analysis of the development of natural hydrological and erosion processes in hillslopes (including landslides and gullying), and the study of a fluvial network is crucial to assess: (i) the complex relationships between hillslopes and channels; (ii) the temporal variability of sediment transport in relation to the occurrence of rainfall events and the soil humidity characteristics; (iii) the location of runoff, and sediment sources and sediment sinks and their seasonal variability; (iv) the connectivity between hillslopes and channels, and the factors that enhance or interfere with it (QuiñoneroRubio et al., 2013); and (v) the role of fluvial channels as sediment sources or sinks. Studies at the experimental catchment scale provide a global perspective on what is happening in the landscape, and in some cases what will happen in the near future according to climatic change models or the possible evolution of plant cover. Catchments also enable the study of internal processes, including soil temperature fluctuations, the variability of soil humidity at various depths, and control of the water table. This global perspective of the landscape is essential to understanding the complexity of nature and 
the integrated functioning of hillslopes and channels (Leopold et al., 1964). In fact, it is impossible to separate these elements because they are mutually interdependent. Fluvial channels receive all the "information" produced in the hillslopes in the form of water and sediment. Such "information" includes overland flow, runoff coefficients, and the volume and type of sediment, which condition to a large extent the characteristics of the channel, including the gradient, width, width/depth ratio, and channel morphology. It also includes the occurrence of disjunctions between sediment supply and sediment transport, because of changes in runoff and sediment sources (Trimble, 2009; Vanmaercke et al., 2011b).

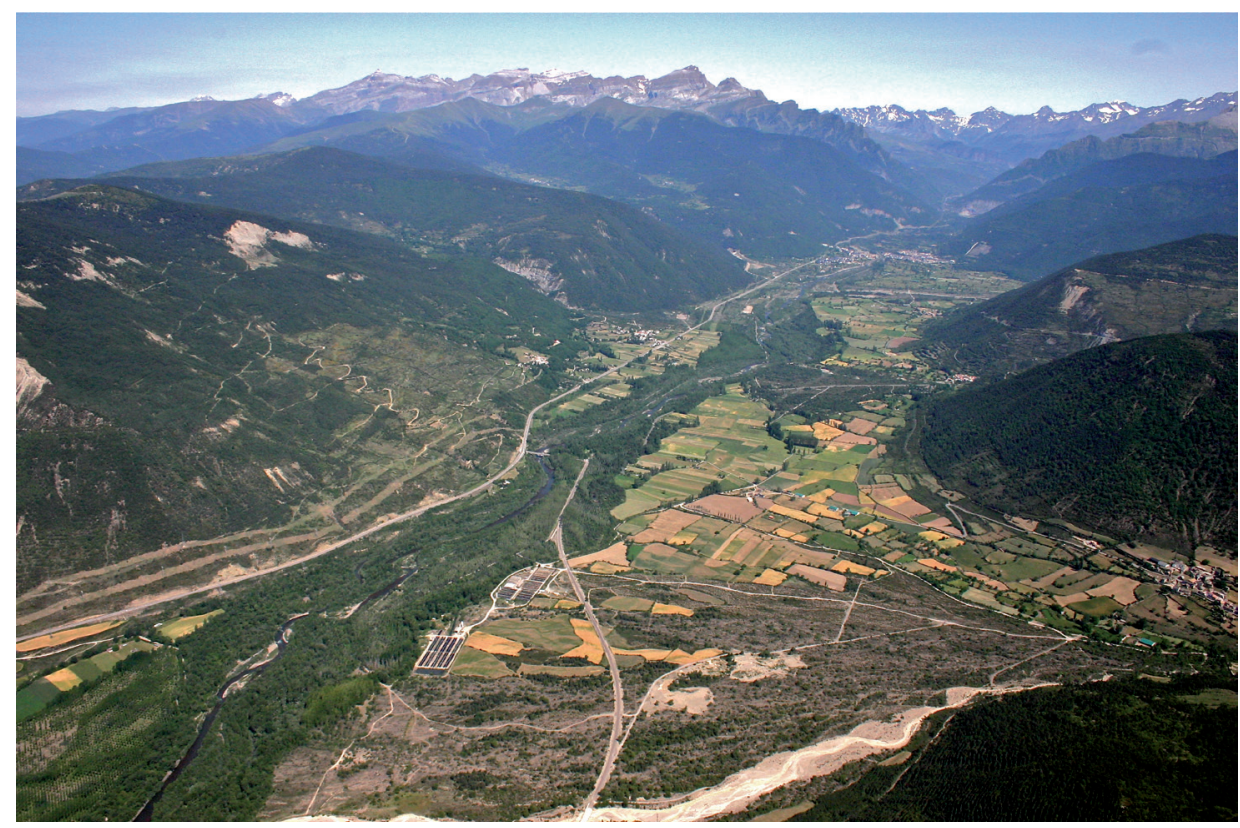

Photo 4. Perspective of the Ribera de Biescas, Upper Gállego Valley, central Spanish Pyrenees. The relief is dominated by three groups of landforms. (i) The uppermost part is occupied by the Inner Ranges, composed of Cretaceous and Eocene limestone and sandstone in which a dramatic relief has developed, with vertical cliffs and sharp divides. (ii) The flysch hills are characterized by smooth divides and homogeneous hillslopes supporting subalpine grasslands, which developed following deforestation of the uppermost parts of the hillslopes, forests and abandoned fields.

The divides correspond to old, pre-Quaternary erosion surfaces. Most of the hillslopes were cultivated until approximately 50-70 years ago, and then abandoned as a consequence of depopulation. Farmland abandonment resulted in plant recolonization and a change in geomorphic activity, dominated until that time by gullying, debris flows and sheet was erosion. (iii) The valley bottom, in which the Gállego River meanders in the alluvial plain, with adjacent riparian vegetation. This is a U-shaped valley formed by successive advances and retreats of the Pleistocene Gállego glacier. Fifty years ago the Gállego River was a typical braided river, because of the large quantity of sediment yielded from the hillslopes. Some semi-active alluvial fans penetrate into the alluvial plain. This view represents the typical complexity of the relief in mountain areas, with very important structural heritage, old erosion processes and recent changes in land usel land cover having resulted in changes in geomorphic processes and fluvial activity. Photo: José Luis Peña. 
The catchment scale approach can address most of the questions that geomorphologists consider, and provides a global interpretation of landscape functioning, although only detailed field observations can resolve some very important problems. It is noteworthy that geomorphic processes dominating in a catchment may not be directly related to the sediment yielded at the outlet from the hillslopes. In many cases the presence of perched flats on hillslopes, or the occurrence of a relatively wide alluvial plain, impedes the transport of sediment to the channel, even in catchments affected by major erosion processes. These are the decoupled hillslopes of Brunsden (2001). In other cases the channel erodes the riverbank sediment, accumulated hundreds or thousands of years ago (Church et al., 1999; Trimble, 1999; Stroosnijder, 2005). Consequently, geomorphologists need to combine the quantitative information from the catchment (discharge, sediment and other features) with detailed mapping of sediment sources and sinks. Tricart (1978) suggested that there is no correlation between erosion of the hillslopes and sediment transport in the streams. He added that measurement of the coarse load in rivers is very important for estimating the useful life and silting velocity of reservoirs, but it cannot be used for calculating the mean erosion rate in the catchment. Therefore, a correlation between sediment transport in the stream and soil loss in experimental plots is meaningless.

There has been recent interest in establishing closer links between geomorphology and ecology, as geomorphological research tends to put emphasis on "the juxtaposition of physical, chemical and biological processes operating in the environment" (Urban and Daniels, 2006). Some geomorphologists and ecologists have presented seminal papers relating soil erosion and the ecophysiological characteristics of plants. Thus, in semiarid and subhumid regions, Cerdà (1997), Cammeraat and Imeson (1999), Puigdefábregas (2005), and Pueyo et al. (2008) noted the existence of positive feedbacks between soil and plants, resulting in the location of plants in "islands of fertility" around which bare areas tend to export water and sediment. The detailed organization of plant cover explains the occurrence (or absence) of erosion processes in hillslopes, and the connectivity with fluvial channels. Cooperation between geomorphologists and ecologists could contribute to better understand the evolution of patchy vegetation (Thornes, 1990; Gallart et al., 1993; Valentin et al., 1999; Kefi et al., 2007), and to the identification of early warning signs of critical transitions or catastrophic shifts (Scheffer et al., 2009; Alfieri et al., 2012; Valiente-Banuet and Verdú, 2013; Alatorre et al., 2014). Similarly, studies on the resistance and resilience of vegetation to droughts, extreme rainfall events, fire and overgrazing are crucial for the control of soil erosion and transport. A major challenge for the future is the development of models enabling forecasting of shifts in geomorphic systems (Poesen et al., 2003).

Ecologists are increasingly aware of how the distribution of organisms is controlled by geomorphic processes and landforms (Stallins, 2006). For instance, water fluxes have a critical role in the redistribution of nutrients at the hillslope and catchment scales, which conditions the distribution of many plants and animals, and traditional grazing management (Pueyo, 2013). The spatial organization of runoff and sediment generation and sink areas also affects the distribution of plant species according to their need for water and nutrients. Conversely, the organization of plants and their communities 
affects the occurrence of geomorphic processes, the loss of soil, and in the long term the development of landforms. This is ecology and this is geomorphology!

There are many other examples of interaction between ecological and geomorphological processes. Thus, in the Mediterranean region and other areas of the world the abandonment of old cultivated fields has led to plant colonization in a process conditioned by highly complex interrelationships among land use prior to abandonment, the state of the soil at the time of abandonment, and climate. At the same time, plant colonization controls erosion, which conditions the features of plant colonization and its spatial organization (García-Ruiz and Lana-Renault, 2011). This parallels the interrelationships between geomorphology and animals. Rice et al. (2014) reported a correlation between the daily activity of an invasive crayfish in British rivers and the pattern of suspended sediment transport, and Borghi et al. (1990) demonstrated the important role of micro-mammals in conditioning the soil for erosion in the subalpine belt of the Pyrenees.

\section{Conclusions}

Geomorphology is a global science that is (mainly) based on field observations, and which increasingly involves the use of laboratory and computer techniques. As it can be defined as the science that studies the evolution and spatial organization of landforms at different temporal and spatial scales, it is located at the intersection of geography and geology, with increasing influences of ecology, physics and chemistry. Consequently, it is a highly complex science at the core of environmental change. It is true that geomorphological studies can involve the analysis of detailed aspects of landforms (e.g. scree deposits), the evolution of soil humidity, or the factors influencing rock weathering, but the final objective is to put that analysis in a broader temporal and spatial context: the explanation of landscapes and landforms.

Landforms are the result of the activity of geomorphic processes on geological structures over varying temporal scales. Each landform is the consequence of complex interactions between bedrock, climate, biological activity, geomorphic processes and time. The role of geomorphologists is to unravel this complexity from the contemporary relief, where the remnants of past deposits and landforms constitute a palimpsest from which most information has disappeared. This requires much imagination, but as Baker and Twidale (1991) noted in relation to Albert Einstein "imagination is more important than knowledge", a principle sometimes forgotten by many scientists.

A gap is progressively opening between "historical" and "environmental" geomorphologists. They correspond to different perceptions of geomorphology, and in some cases use very different techniques. However, it is important to understand that the historical and environmental aspects are parts of the same problem: relief development at distinct temporal scales. The contemporary situation serves to interpret the history; the historical conditions underpin the contemporary reality. This is global geomorphology: the interpretation of landforms and landscape variability in relation to historical evolution and contemporary processes. For geomorphologists good at their science it is impossible 
to differentiate between the past and the present. Newer geomorphologists may not have heard of the French geographer Jean Tricart. He wrote many books and published many papers, and opened the minds of many geographers and geologists to the importance of being global in geomorphology. To translate from Tricart (1978), written in French almost 40 years ago: "To carry out scientific research in an interdisciplinary way is always more difficult than following the analytical way protected by the earflap of each specialty. Besides, Nature totally ignores our division in branches of knowledge, which is only the result of a convenience invented by scientists". Fortunately, all is not lost. Some geomorphologists want to be global and to contribute to interpretation of the landscape. They observe during long fieldwork journeys, best done from the highest part of the relief, and organize and classify landforms according to their relative topographical position. They analyze deposits at mid-hillslope or the valley bottom, compare the ages, and establish a succession of events. In parallel, they interpret the geomorphic processes, their spatial distribution and relationships to topographical and pedological factors, the distribution of plant cover and its recent history, and the history of land use. Sometimes they collaborate with ecologists. This is global. This is geomorphology, a linking science that is comfortable among geography and geology.

\section{Acknowledgements}

Support for this research was provided by the projects INDICA (CGL201127753-C02-01), funded by the Spanish Ministry of Economy and Competitiveness, and CRYORDESA funded by the Spanish National Parks of the Ministry of Environment, and an agreement between the CSIC and the Spanish Ministry of Environment (RESEL). The Geomorphology and Global Change research group was financed by the Aragón Government and the European Social Fund (ESF-FSE).

\section{References}

Alatorre, L.C., Miramontes-Beltrán, S., García-Peña, A.K., Díaz-Caravantes, R., Bravo, L.C. 2014. Evolución de la dinámica vegetal mediante una serie de imágenes Landsat TM (19862011): Región central de Chihuahua, México. Cuadernos de Investigación Geográfica 40 (2), 449-476.

Alfieri, L., Salamon, P., Pappenberger, Wetterhall, F. 2012. Operational early warning systems for water-related hazards in Europe. Environmental Science and Policy 21, 35-49.

Baker, V.R., Twidale, C.R. 1991. The reenchantment of geomorphology. Geomorphology 4, 73100.

Bauer, B.O. 2004. Geomorphology. In: A.S. Goudie (ed.), Encyclopedia of Geomorphology, Routledge, London, pp. 428-435.

Borghi, C.E., Giannoni, S.M., Martínez-Rica, J.P. 1990. Soil removed by voles of the genus Pitymys in the Spanish Pyrenees. Pirineos 136, 3-18.

Brunsden, D. 2001. A critical assessment of the sensitivity concept in Geomorphology. Catena 42, 99-123.

Brunsden D., Thornes, J.B. 1979. Landscape sensitivity and change. Transactions of the Institute of British Geographers NS 4, 463-484. 
Cammeraat, E.L.H. 2004. Scale dependent thresholds in hydrological and erosion response of a semi-arid catchment in Southeast Spain. Agriculture, Ecosystems and Environment 104, 317-332.

Cammeraat, L.H., Imeson, A.C. 1999. The evolution and significance of soil-vegetation patterns following land abandonment and fire in Spain. Catena 37, 107-127.

Capel, H. 1983. Positivismo y antipositivismo en la ciencia geográfica. El ejemplo de la geomorfología. Geo Crítica. Cuadernos Críticos de Geografía Humana 43, 55 pp., Barcelona.

Cerdà, A. 1997. The effect of patchy distribution of Stipa tenacissima L. on runoff and erosion. Journal of Arid Environments 36, 37-51.

Chorley, R.J., Beckinsale, R.P., Dunn, A.J. 1964. The history of the study of landforms or the development of Geomorphology. Vol. 1: Geomorphology before Davis. Methuen, London, $678 \mathrm{pp}$.

Church, M., Ham, D., Hassan, M., Slaymaker, H.O. 1999. Fluvial clastic sediment yield in Canada: scaled analysis. Canadian Journal of Earth Sciences 36, 1267-1280.

Davis, W.M. 1899. The geographical cycle. The Geographical Journal 14, 481-504.

De Boer, D.H. 1992. Hierarchies and spatial scale in process geomorphology: a review. Geomorphology 4, 303-318.

De Martonne, E. 1913. Le climat, facteur du relief. Scientia 13, 339-355.

De Vente, J., Poesen, J. 2005. Predicting soil erosion and sediment yield at the basin scale: Scale issues and semi-quantitative models. Earth-Science Reviews 71, 95-125.

De Vente, J., Poesen, J., Arabkhedri, M., Verstraeten, G. 2007. The sediment delivery problem revisited. Progress in Physical Geography 31, 155-178.

Derruau, M. 1965. Précis de Géomorphologie, Masson, Paris, 415 pp.

Gallart, F., Puigdefábregas, J., del Barrio, G. 1993. Computer simulation in high mountain terracettes as intersection between vegetation growth and sediment movement. Catena 20, 529-542.

García Fernández, J. 2001. Geografía física o ciencias naturales. Investigaciones Geográficas 25, 33-49.

García-Ruiz, J.M., Lana-Renault, N. 2011. Hydrological and erosive consequences of farmland abandonment in Europe, with special reference to the Mediterranean region - A review. Agriculture, Ecosystems and Environment 140, 317-338.

García-Ruiz, J.M., Lana-Renault, N., Beguería, S., Lasanta, T., Regüés, D., Nadal-Romero, E., Serrano-Muela, P., López-Moreno, J.I., Alvera, B., Martí-Bono, C., Alatorre, L.C. 2010. From plot to regional scales: Interactions of slope and catchment hydrological and geomorphic processes in the Spanish Pyrenees. Geomorphology 120, 248-257.

Gómez-Villar, A., Sanjuán, Y., García-Ruiz, J.M., Nadal-Romero, E., Álvarez-Martínez, J., Arnáez, J., Serrano-Muela, M.P. 2014. Sediment organization and adjustment in a torrential reach of the Upper Ijuez River, Central Spanish Pyrenees. Cuadernos de Investigación Geográfica 40 (1), 191-214.

Goudie, A. 1981. The human impact on the natural environment. Basil Blackwell, Oxford, 338 pp.

Goudie, A.S. 2002. Aesthetics and relevance in geomorphological outreach. Geomorphology 47, 245-249.

Gutiérrez, M. 2005. Climatic Geomorphology. Elsevier, Amsterdam, 760 pp.

Horton, R.E. 1945. Erosional development of streams and their drainage basins: hydrophysical approach to quantitative morphology. Geological Society of America Bulletin 56, 275-370.

Keesstra, S.D., Maroulis, J., Argaman, E., Voogt, A., Wittenberg, L. 2014. Effects of controlled fire on hydrology and erosion under simulated rainfall. Cuadernos de Investigación Geográfica 40 (2), 269-293. 
Kéfi, S., Rietkerk, M., Alados, C.L., Pueyo, Y., Papanastasis, V.P., ElAich, A. 2007. Spatial vegetation patterns and imminent desertification in Mediterranean arid ecosystems. Nature 449, 213-217.

Leopold, L.B., Wolman, M.G., Miller, J.P. 1964. Fluvial processes in Geomorphology. Freeman and Co., San Francisco, 522 pp.

Ollero, A., Ibisate, A., Acín, V., Ballarín, D., Besne, P., Díaz, E., Ferrer-Boix, C., Granado, D., Herrero, X., Horacio, J., Martín-Vide, J.P., Mesanza, A., Mora, D., Sánchez, I. 2014. Geomorfología y restauración fluvial: seguimiento del derribo de presas en Gipuzkoa. Cuadernos de Investigación Geográfica 40 (1), 67-88.

Ortega, N. 1977. La geografía, ¿discurso inútil o saber estratégico? Agricultura y Sociedad 5, 210-222.

Panizza, M. 1996. Environmental Geomorphology. Elsevier, Amsterdam, 268 pp.

Parsons, A.J., Brazier, R.E., Wainwright, J., Powell, D.M. 2006. Scale relationships in hillslope runoff and erosion. Earth Surface Processes and Landforms 31 (11), 1384-1393.

Passarge, S. 1931. Geomorfología, Editorial Labor, Barcelona, pp. 189.

Phillips, J.D. 1992a.Nonlinear dynamical systems in geomorphology: Revolution or evolution? Geomorphology 5, 219-229.

Phillips, J.D. 1992b. The end of equilibrium? Geomorphology 5, 195-201.

Poesen, J., Nachtergaele, J., Verstraeten, G., Valentin, C 2003. Gully erosion and environmental change: importance and research needs. Catena 50, 91-133.

Pueyo, Y. 2013. Aportación de los modelos ecohidrológicos con feedbacks al conocimiento del funcionamiento de los ecosistemas de zonas áridas y semi-áridas. Cuadernos de Investigación Geográfica 39 (2), 243-258.

Pueyo, Y., Kéfi, S., Alados, C.L., Rietkerk, M. 2008. Dispersal strategies and spatial organization of vegetation in arid ecosystems. Oikos 117, 1522-1532.

Puigdefábregas, J. 2005. The role of vegetation patterns in structuring runoff and sediment fluxed in drylands. Earth Surface Processes and Landforms 30, 133-147.

Quiñonero-Rubio, J.M., Boix-Fayos, C., de Vente, J. 2013. Desarrollo y aplicación de un índice multifactorial de conectividad de sedimentos a escala de Cuenca. Cuadernos de Investigación Geográfica 39 (2), 203-223.

Redondo Vega, J.M., Santos González, J., Gutiérrez González, R.B., Gómez Villar, A. 2013. Ejemplos de formas de relieve indicadoras de diferentes paleoclimas en la Cordillera Cantábrica. Polígonos. Revista de Geografía 24, 163-181.

Renwick, W.H. 1992. Equilibrium, disequilibrium, and nonequilibrium landforms in the landscape. Geomorphology 5, 265-276.

Rhoads, B.L., Thorn, C.E. 1993. Geomorphology as science: the role of theory. Geomorphology 6, 287-307.

Rice, S.P., Johnson, M.F., Extence, C., Reeds, J., Longstaff, H. 2014. Diel patterns of suspended sediment flux and the zoogeomorphic agency of invasive crayfish. Cuadernos de Investigación Geográfica 40 (1), 7-28.

Sack, D. 1992. New wine in old bottles: the historiography of a paradigm change. Geomorphology 5, 251-263.

Sanchis-Ibor, C., Segura-Beltrán, F. 2014. Spatial variability of channel changes in a Mediterranean ephemeral stream in the last six decades (1946-2006). Cuadernos de Investigación Geográfica 40 (1), 89-118.

Sanjuán, Y., Gómez-Villar, A., Nadal-Romero, E., Álvarez-Martínez, J., Arnáez, J., SerranoMuela, M.P., Rubiales, J.M., González-Sampériz, P., García-Ruiz, J.M. 2014. Linking land cover changes in the sub-alpine and montane belts to changes in a torrential river. Land Degradation and Development, DOI: 10.1002/ldr.2294. 
Scheffer, M., Bascompte, J., Brock, W.A., Brovkin, V., Carpenter, S.R., Dakos, V., Held, H, van Nes, E.H., Rietkerk, M., Sugihara, G. 2009. Early-warning signals for critical transitions. Nature 461, 53-59.

Scheidegger, A.E. 1992. Limitations of the system approach in geomorphology. Geomorphology 5, 213-217.

Schumm, S.A. 1977. The fluvial system. Wiley, New York, 338 pp.

Stallins, J.A. 2006. Geomorphology and Ecology: Unifying themes for complex systems in biogeomorphology. Geomorphology 77, 207-2016.

Strahler, A.N. 1952. Dynamic basis of Geomorphology. Geological Society of America Bulletin 66, 923-938.

Stroosnijder, L. 2005. Measurement of erosion: Is it possible? Catena 64, 162-173.

Thomas, M.F. 2001. Landscape sensitivity in time and space - an introduction. Catena 42, 83-98.

Thorn, C.E. 1988. An introduction to theoretical Geomorphology. Unwin Hyman, Boston, 247 pp.

Thornes, J.B. 1979. Introduction. In: C. Embleton and J. Thornes (Eds.), Process in Geomorphology. Edward Arnold, London, pp. 1-10.

Thornes, J.B. 1990. The interaction of erosional and vegetation dynamics in land degradation: spatial outcomes. In J.B. Thornes (ed.), Vegetation and erosion, John Wiley and Sons, Chichester, pp. 41-53.

Tricart, J. 1965. Principes et méthodes de la Géomorphologie. Masson, Paris, 496 pp.

Tricart, J. 1978. Géomorphologie applicable. Masson, Paris, 204 pp.

Trimble, S.A. 1999. Decreased rates of alluvial sediment storage in the Coon Creek basin, Wisconsin, 1975-93. Science 285, 1244-1246.

Trimble, S.W. 2009. Fluvial processes, morphology and sediment budgets in the Coon Creek Basin, WI, USA, 1975-1993. Geomorphology 108, 8-23.

Urban, M.A., Daniels, M. 2006. Introduction: Exploring the links between geomorphology and Ecology. Geomorphology 77, 203-206.

Valentin, C., d'Herbes, J.M., Poesen, J. 1999. Soil and water components of banded vegetation patterns. Catena 37 (1-2), 1-24.

Valiente-Banuet, A., Verdú, M. 2013. Human impacts on multiple ecological networks act synergistically to drive ecosystem collapse. Frontiers of Ecological Environment 11, 408413.

Vanmaercke, M., Poesen, J., Vertraeten, G., de Vente, J., Ocakoglu, F. 2011a. Sediment yield in Europe: Spatial patterns and scale dependency. Geomorphology 130, 142-161.

Vanmaercke, M., Poesen, J., Maetens, W., de Vente, J., Verstraeten, G. 2011b. Sediment yield as a desertification risk indicator. Science of the Total Environment 409, 1715-1725.

Vanmaercke, M., Maetens, W., Poesen, J., Jankauskas, B., Jankauskiene, G., Verstraeten, G., de Vente, J. 2012. A comparison of measured catchment sediment yields with measured and predicted hillslope erosion rates in Europe. Journal of Soils and Sediments 12, 586-602.

White, S., García-Ruiz, J.M., Martí, C., Valero, B., Errea, M.P., Gómez-Villar, A. 1997. The 1996 Biescas campsite disaster in the Central Spanish Pyrenees, and its temporal and spatial context. Hydrological Processes 11, 1797-1812. 